\title{
Investments in Information Technology (IT) and Bank Business Performance in Ghana
}

\author{
Gideon T.Y Leckson-Leckey (Corresponding author) \\ Marketing \& Corporate Affairs Dept, The Trust Bank (TTB)-Ghana \\ No. 68 Nkrumah Ave. P. O. Box 1862, Accra-Ghana \\ Tel: 233-24-334-8489 or 233-277-263-677_E-mail: giddo18@yahoo.com or glleckey@ttbgh.com \\ Kofi A. Osei \\ University of Ghana Business School, Legon \\ P. O. Box LG 78, Legon, Accra -Ghana \\ Tel: 233-20-818-0424Ｅ-mail: kaosei@ug.edu.gh \\ Simon K. Harvey \\ University of Ghana Business School, Legon \\ P. O. Box LG 78, Legon, Accra -Ghana \\ Tel: 233-24-436-8335 E-mail: sharvey@ug.edu.gh
}

Received: July 15, 2010 Accepted: August 5, 2010 doi:10.5539/ijef.v3n2p133

\begin{abstract}
This study seeks to ascertain and document the extent to which investment in IT by banks in Ghana can impact on their profitability using the Balanced Scorecard (BSC) framework. The study uses the extensive panel dataset of 15 banks sampled from the Ghanaian banking industry over a 10-year period (1998-2007. The study finds that banks which maintain high levels of investments in IT increased return on assets (ROA) and return on equity (ROE).
\end{abstract}

Keywords: Balanced Scorecard, IT, ROA, ROE, Performance, Banks, Ghana

\section{Introduction}

According to Levitt (1992), technology presents itself as a powerful force that drives the world towards a converging commonality. From the beginning of human era, technology has been one of the most essential and most important factors for the development of mankind (Coombs et al., 1987). Innovations in information processing, telecommunications, and related technologies - known collectively as "Information Technology" (IT) or sometimes Information Communication Technologies (ICTs) - is defined by Ige (1995) as the modern handling of information by electronic means, which involves its access, storage, processing, transportation or transfer and delivery. Langdon and Langdon, (2006) also define IT as a set of interrelated components that collect (or remove), process, store and distribute information to support decision making, co-ordination and control. IT also helps managers and workers to analyse problems, visualize complex subjects and create new products.

IT including computer based information systems used by an organisation and their underlying technologies have propelled changes in the banking sector (Langdon and Langdon, 2006). Technological innovation for that matter affects not just banking and financial services, but also the direction of an economy and its capacity for continual and sustainable growth. Most banking industry and development analysts assert that technological change is one of the important factors underlying the dynamics in the banking industry structure and performance today which leads to cost competitiveness and diversification into new lines of business to improve profitability, through strategic positioning and processes.

In order to either sustain or enhance on their competitive advantage in an ostensibly growing industry, banking institutions invest fortune or substantial amounts in IT resources, which could also reveal new means of creating value for both the bank and the customer. However, expenditures that affect banks' ability to compete are usually discretionary. These expenditures are made to sustain or increase shareholder value through (1) a revenue growth strategy by expanding into new markets, new customers, products and services and (2) a productivity strategy whereby improvements are made in the cost structure and in asset utilization. Technology is being increasingly employed in service organisations to enhance customer service quality and delivery, reduce costs, and standardise core service offerings (Kelly, 1989; Dannenberg and Kellner, 1998; Lee and Lin, 2005; Bauer et al., 2005; Gounaris 
et al., 2005). These tend to increase the profitability of banks marginally.

The craze in the adoption of technologies like Internet, SMS, and ATM by banks of developing economies has been as a result of the desire to be above competition and the struggle for strategic market share, as the "cake is big, but the slices are smaller" as well as a means to manage their risk positions and pricing. At the same time, new off-the-shelf electronic services such as online retail banking are making it possible for very small institutions to take advantage of new technologies at quite reasonable costs. These developments have ultimately changed the competitive landscape in the financial services and also made it easier for foreign competitors to penetrate local markets.

Studies about impact of IT investments on banks' business value and performance have received massive attention in Europe, the Americas and Asia with mixed results. Nevertheless, the focus on Africa and West Africa, for that matter, tends to be parsimonious in comparison with the theoretical and empirical evidences from the developed economies. Whether the level of investment done in IT actually brings real benefits to the banks, is still a matter of debate in academic circles. Researchers and practitioners have agreed to the fact that traditional analysis - focused only on financial or technological aspects - is not complete. Different alternative methods have been suggested to complement evaluation of IT investment.

This paper contributes to the existing literature, by providing empirical evidence regarding the effects of IT investments on Bank business performance in Ghana. We believe our understanding of this subject as one of the early attempts to pave the way for further investigations by both industry and academia is apposite and would enable researchers, investors, management and IT managers to be able to deal with and justify the resources spent on technology, as well as plan, implement and evaluate IT strategies.

The remainder of the paper is structured as follows; section 2 reviews some of the literature on the topic. Section 3 describes the methodology of the study. Section 4 shows the results, whilst section 5 gives a summary and conclusions of the study.

\section{Literature Review}

\subsection{Clash of Expectations - Productivity Paradox of I.T}

Productivity is the fundamental measure of a technology's contribution, which creates room for competitive advantage. While major success stories exist, so do equally impressive failures (see Kemerer and Sosa, 1991; Schneider, 1987). Since the beginnings of the computing era (Kaufman, 1966), people have suggested that the implementation of computing technologies would have a series of positive effects (McLean and Soden, 1977; McFarlen, 1984; Porter and Millar, 1985; Parsons, 1983; Cash and Konsynski, 1986). These authors, according to Bruque et al (2002), claimed that IT could play a strategic role: by affecting the conditions in which products are supplied and produced, the market structure itself or economies of production. From the strategic point of view, IT could affect every one of Porter's competitive strategies (1980), whether cost leadership, differentiation or specialization in a market niche (Bruque et al, 2002).

The perception, which drew attention to the zero, or even negative productivity increases of the work factor of firms that used information technology intensively (Solow, 1987), clashed with the techno-enthusiasm that was dominant in the eighties (Parsons, 1983; Mcfarlan, 1984). This was evident in two authors with differing approaches (Strassmann, 1990 and Brynjolfsson, 1993), who affirmed that the decrease in productivity of the work factor coincided with the period in which the companies invested enormous sums in equipment and computing systems (Strassmann, 1997. p.1). Thus, the Productivity Paradox phrase came into being when large investments in Information Technology (IT) apparently failed to produce the much-expected significant increases in productivity in the 1980s and early 1990s and the early acclaimed positive effects on two levels.

The first is at the industry or economy-wide level. Nobel Prize winning economist, Robert Solow, who wrote, "We see the computer age everywhere except in the productivity statistics," as quoted by Brynjolfsson and Hitt (1998), summed this up in 1987. The second productivity paradox was observed at the company level, where "there was no correlation whatsoever between expenditures for information technologies and any known measure of profitability" (Strassmann, 1990).

Many connoisseurs of early studies examined the correlation between IT spending ratios and various performance measurements, such as profits or stock returns (Dos Santos, Peffers and Mauer, 1993; Strassmann, 1997). Since the correlation was either zero or very low, some concluded that computer investments have been unproductive. However, spending more on computers should generate higher profitability or stock market returns (Lim, Richardson and Robert, 2004). Zero correlation could be interpreted as indicating 'normal' ratios to investments in IT (Brynjolfsson and Hitt, 1998).

Over the past decades, both the academia and industry have periodically revisited the so-called "productivity paradox" of Information Technology. Despite the enormous promise of IT to effect "the biggest technological 
revolution men have known" (Snow, 1996), disillusionment and even frustration with the technology are evident in statements like, "No, computers do not boost productivity, at least not most of the time" (Economist, 1990) and headlines like, "Computer Data Overload Limits Productivity gains" (Zachary, 1991).

Interest in the "productivity paradox" has generated a significant amount of research. Although extensive researches have been conducted on the subject, there is little evidence that information technology significantly increased productivity in the 1970s and 1980s (Brynjolfsson and Yang, 1996). The results were aptly characterized as "you can see the computer age everywhere, but not in the productivity statistics"(Solow, 1987) and Bakos and Kremer (1992) concludes that "these studies have fuelled a controversial debate, primarily because they have failed to document substantial productivity improvements attributable to Information Technology investments".

When Brynjolfsson and Hitt (1993, 1995) and Lichtenberg (1995) among others found firm-level evidence that IT investments earned substantial returns, the media pendulum swung in the opposite direction. Both Mandel (1994) and Magnet (1994) in the BusinessWeek and Fortune media respectively, proclaimed "productivity surge" due to "information technology" and "technology payoff."

Apparently, some believe that this productivity paradox came about because of measurement issues, research methods and datasets. The appropriateness of research methodologies used, the reliability and validity of datasets and the measurement of IT investment research benefits, have been questioned by many researchers including Brynjolfsson (1993). The equivocal results of IT investments, in many cases, are caused by the inconsistency in IT firm performance measurement issues (Willcocks and Lester, 1999).

A study by Crowston and Treacy (1986), on 'impact of IT on enterprise level performance', concluded that attempts to measure the impact of IT were surprisingly unsuccessful and attributed this to the lack of defined variables, which in turn stems from inadequate reference disciplines and methodologies.

Lim et al (2004) asserted that three possible analyses best explain the inconsistencies and swings in research results and the publications of the effects of IT investments on firm performance. First, the nature of the IT expenditures studied by researchers has changed over time. Rai et al (1997) noted that there has been no uniform conceptualisation of IT investments or identification of appropriate performance measures. Second, the nature of economic environment and regulations has changed over time. Third, when new IT is being introduced; early payoffs may not be representative of the long-term value of IT, due to a period of learning or adjustment, and the restructuring of the organisational environment.

IT studies have been characterised by mis-measurement of variety of dependent variables and lags. Agreeably, all of these issues leave the question of effects of IT investments on firm performance open (Lim et al (2004).

\subsection{Empirical Evidence of I.T Productivity \& Performance}

Various works support the sustained evolution towards positions, which are more optimistic about the impact of IT (Hitt and Brynjolfsson, 1995, 1996; Brynjolfsson and Hitt, 1996; Brynjolfsson, Hitt and Yang, 2000; Brynjolfsson and Hitt, 2001). The 1996 researches, involving Hitt and Brynjolfsson, admitted that investment in IT were associated with an increase in productivity of workers who work with information and, additionally, they claim that investments in computing generates greater levels of productivity than any other type of investments, despite the short life-span of this type of tool (Brynjolfsson and Hitt, 1996, p.49-50). However, the researchers maintain that the results obtained did not imply that investing in IT guarantees net productivity gains, but that other factors may influence the relation (Bruque et al, 2002).

Evidence showed off a relation between investment in IT and an improvement in global business performance, and not only productivity of work factor (Brynjolfsson, Hitt and Yang, 2000; Brynjolfsson and Hitt, 2001). Using a global result indicator, Tobin's Q ratio, based on the firm's value in the stock market, they concluded that those firms, which invested more in IT in the period 1987-1994, achieved superior results. More so, the correlation was stronger when the firm, along with the investment in IT which underwent a structural re-organisation involving interdisciplinary workgroups, increases in independent decision-making and support for employees' training.

\subsubsection{I.T and Long-Run Firm Performance}

Investments in IT systems may not have an immediate impact or add value to a firm and are, therefore, more likely to be reflected in future profit streams. Studies show that executives, who make IT investment decisions, are increasingly beginning to focus on factors such as risk avoidance, growth potential, and strategic flexibility in evaluating IT projects (Quinn and Baily 1994). Returns or real benefits of IT may not show up in the accounting ratios, but rather provide some level of real gains to customers of such firms, as well as the company itself, through avoidance of potential losses (Bharadwaj, et al, 1999). 


\subsection{Security and I.T Investments}

Computer security is important to all businesses particularly so for the banks (Checkley 1994). According to O' Leary et, al (1989), two issues come to mind when banks talk about security. They are privacy and security, controlling who gets access to the bank's computer system and its programmes, and what time to access it. They explain privacy as being primarily a personal concern; it is the assurance from the bank to individual banking customer that personal information will be used properly; is accurate and is protected against improper access.

Computer crime - the use of computers to steal money, goods, information or computer time and piracy as well as stealing or unauthorised copying of programmes or software can be very expensive to a bank. These crimes have been on the ascendancy in the last decade. Currently in Ghana, computer-based fraud (originally known locally as 'sakawa') is on the ascendancy with the internet and other forms of technology, being tools employed to exploit people. Though only fewer cases may exist, the banking system has not been spared.

\section{Methodology}

The study uses financial statements data of 15 banks in Ghana for a 10-year period (1998-2007). The reason for the choice of 10 years is due to ease of access to data. This study uses Panel methodology because of the nature of the data collected.

\subsection{Conceptual Framework}

The conceptual framework employed in the study is the Balanced Score Card (BSC) approach (Kaplan and Norton, 1992) and (Kim and Davidson, 2004) to measure the effects of IT investments on banks' business performance. The Balanced Score Card (BSC) framework is applied to four sets of measures that are designed to capture banks strategies as far as IT investments are concerned. Due to mixed results on IT investments and firm performance, the BSC framework provides a useful framework in measuring the economic consequences of strategic use of IT, because the BSC provides a specification of strategic objectives and appropriate performance measures such as a firm's (1) learning and growth activities (2) internal business processes (3) customer value and (4) financial performance (Kim and Davidson, 2004).

\subsection{Analytical framework}

We analyse the relationship within the framework, that investments in Information Technology (I.T) influence firm performance, i.e. IT has a positive effect on performance. In order to avoid any interference by other variables, this research includes control variables which are firm characteristics drawn from extant literature. To avoid the impact caused by other variables that are absent from the models used in this research, this study refers to prior research of Kim and Davidson (2004).

We investigate the relationship between investment in IT and bank performance by using two equations based on return on assets (ROA) and return on equity (ROE).

The following hypothesis is thus constructed in line with the objective of the study.

$\mathrm{H}_{1}$ : Banks with high IT investment levels have greater positive impact on profitability (ROA and ROE) than those with low IT level.

Equation 1

$$
\mathrm{ROA} A_{i t}=\lambda_{0}+\lambda_{1} \text { Bran }+\lambda_{2} \text { Growth }_{i t}+\lambda_{3} \text { LNIR }_{i t}+\lambda_{4} \text { LNIE }_{i t}+\lambda_{5} \text { LITEXP }_{i t}+\lambda_{6} \text { LITNDX }_{i t}+\varepsilon_{i t} \ldots
$$

$\mathrm{ROA}_{\mathrm{it}}=$ Return on Assets (ROA) of bank $\mathrm{i}$ at the end of fiscal year $\mathrm{t}$.

$\mathrm{Bran}_{\mathrm{it}}=$ Total number of branches of bank $\mathrm{i}$ at the end of year $\mathrm{t}$

Growth $_{\text {it }}=$ Growth in Net-Interest income of bank $\mathrm{i}$ at the end of year $\mathrm{t}$.

$\mathrm{LNIR}_{\text {it }}=$ the natural log of Non-Interest Revenue of the bank $\mathrm{i}$ at the end of fiscal year $\mathrm{t}$.

$\mathrm{LNIE}_{\mathrm{it}}=$ the natural log of Non-Interest Expenses of bank $\mathrm{i}$ at the end of fiscal year $\mathrm{t}$.

LITEXP $_{\text {it }}=$ the natural log of IT investment of bank $\mathrm{i}$ at the end of fiscal year $\mathrm{t}$

LITNDX $_{\mathrm{it}}=$ the natural log of the interactive dummy variable between ITEXP and IT level (i.e., NDX-an index variable where high IT level Banks equal 1 and low IT level firms is 0).

Return on Assets as a profitability measure, notated as $\mathrm{ROA}_{\text {it }}$ in equation (1) is calculated as the ratio of profit after tax divided by total assets of each bank. The NIR, NIE and Growth are control variables since ROA of each bank is affected by them. The sign of $\lambda_{o}$ is expected to be positive and statistically significant. The signs of $\lambda_{1}, \lambda_{2}$ are expected to be positive and statistically significant. However, the $\operatorname{sign} \lambda_{3}$ is expected to be negative and also significant. The key components of this regression are $\lambda_{4}$, the estimated coefficient of IT expenditure, $\lambda_{5}$, the 
estimated coefficient of the interactive dummy variables between ITEXP $P_{i t}$ and IT level. These estimates coefficients provides evidence on whether the banks that spend more on IT (i.e. high IT level firms) have a greater impact on the financial performance.

\section{Equation 2}

$\mathrm{R} O E_{i t}=\delta_{0}+\delta_{1} R O A_{i t}+\delta_{2}$ Growth $_{i t}+\delta_{3}$ LNIR $_{i t}+\delta_{4}$ LNIE $_{i t}+\delta_{5}$ LITEXP $_{i t}+\delta_{6}$ LITNDX $_{i t}+\varepsilon_{i t} \ldots \ldots \ldots . . .$.

Where,

$\mathrm{ROE}_{\mathrm{it}}=$ Return on Equity (ROE) of bank $i$ at the end of fiscal year $\mathrm{t}$.

$\mathrm{ROA}_{\mathrm{it}}=$ Return on Assets (ROA) of bank $\mathrm{i}$ at the end of fiscal year $\mathrm{t}$.

Notations for other variables are the same as shown in equation (1).

Return on Equity as another profitability measure, noted as ROE in equation (2) is calculated as the profit after tax divided by Equity, which is represented by shareholders fund of each bank. The NIR, NIE and Growth are control variables since ROE of each bank is affected by them. The signs of $\delta_{0}, \delta_{1}, \delta_{2}$, and $\delta_{3}$ are expected to be positive and statistically significant. However, the $\operatorname{sign} \delta_{4}$ is expected to be negative and also significant. The key components of this regression are $\delta_{5}$, the estimated coefficient of IT expenditure, $\delta_{6}$, the estimated coefficient of the interactive dummy variables between ITEXP $P_{i t}$ and IT level. These estimated coefficients provide evidence on whether the banks that spend more on IT (i.e. high IT level firms) have a greater impact on the financial performance.

\subsection{Key Variable}

Key independent variable in this study, IT investments (ITEXP) was collected from every bank as it is not publicly available for all the banks. In the instance where data was not available, figures reported in financial statements as investment on computers was used as a proxy for IT investments. IT level is calculated as the average of IT investments / expenditures of all banks for the sample years 1998-2007. An Index variable (NDX) for IT level is assigned to all banks. The number 1 is assigned to firms exceeding the mean of all firms' IT expenditures (High IT firms) and 0 for others (Low IT firms). Thus an interactive dummy variable, ITNDX ${ }_{\text {it, }}$ is calculated by IT expenditures (ITEXP ${ }_{i t}$ ) multiplied by the index variable (NDX) for IT level. The study used t-statistics to compare the labour productivity ratio between two groups (high IT level banks versus low IT level banks).

\section{Empirical Results}

\subsection{Descriptive Statistics}

Table 1 shows the descriptive statistics of variables and one-sample statistics of the study. The descriptive statistics include mean, standard deviation, minimum and maximum. The one-sample test at $5 \%$ (two-tail test) significant level indicates that all the variables used in this study are significant. (See Table 1 below)

\subsection{Empirical Analyses and Results of I.T Level of Respondent Banks}

The Independent-Samples T-Test procedure was used to compare and test for difference of means for major performance variables between the two groups of high IT investing banks and low IT investing banks. As shown in table 2, the mean of $\left(\right.$ LITEXP $_{\text {it }}$ and LITNDX $\left._{\text {it }}\right)$ is greater for high IT level banks than for low IT level Banks, supporting the findings of Kim and Davidson (2004). To test the robustness of the results in table 2, the Mann-Whitney U statistics, and the Wald-Wolfowitz Test, both non-parametric tests were conducted and the significance results were similar to the results of the independent sample T-test statistics.

Further, table 2 shows that the means of all the variables, except equity ratio (EQTR) is greater for high IT level banks than for low IT level banks. Of these variables, only GROWTH and EQTR are not statistically significant at $90 \%, 95 \%$ and $99 \%$ with t-values of 0.138 and -0.145 respectively. The rest are statistically significant and greater for high IT level banks than for low IT level banks. Since exogenous factors, which may affect these variables can't be controlled in t-test, the t-test results must be cautiously analysed and interpreted. Thus the employment of the regression approach to test whether the effects of IT investments on cost structure, market share, operation profits and profitability ratios is different depending on the levels of IT investment.

\subsection{Empirical Panel Regression Results}

\subsubsection{Unit Root Test}

A crucial property of any economic variable influencing the behaviour of statistics in econometric models is the extent to which that variable is stationary. Testing for unit roots in time series is now common practice among applied researchers. However, testing for panel unit roots is quite recent and many researches and thesis applying panel data still disregard this crucial step. Panel unit root tests are similar but not identical to unit root tests carried 
out in time series analysis. The presence of a unit root is strong confirmation that the series is non-stationary. A very small p-value for the test statistic in all the processes mentioned above, assures us that a panel is stationary so OLS and GLS models if employed are unbiased and efficient. We therefore computed the summary panel unit root test, using individual fixed effects and linear trends as regressors, and automatic lag difference term and bandwidth selection. The summary test was used in order to ascertain the stationarity by both the common root and individual root methods. The results for the panel unit root test are presented in table 3 for all variables.

The results indicate the absence of a unit root, as the LLC, Breitung, IPS, and both Fisher tests fail to accept the null of a unit root with statistics of $-11.592,-11.925,-15.054,308.549$ and 357.530 respectively. Therefore OLS or GLS regressions if employed would be unbiased and efficient irrespective of the results of other models if employed.

4.3.2 Profitability: Returns on Assets (ROA) and Return on Equity (ROE)

The results of the regression equations (1) and (2) to test the Relationship between IT expenditure and bank performance is shown as table 4 .

4.3.3 Return on Assets (ROA)

The estimated coefficients growth and Lnir $\left(\lambda_{2}\right.$ and $\left.\lambda_{4}\right)$ are positive as expected and statistically significant. Obviously increases in interest margin and non-interest revenues would lead to significant increases in net profit, thereby increasing ROA. As expected, the coefficient $\lambda_{4}$ is negative as non-interest expenses (NIE) tends to lower profits of banks and as such, lowers ROA. Therefore it would be expected that for ROA to increase considerably, then NIE should be kept at the barest minimum.

The estimated coefficient of $\lambda_{5}$ is negative. This is an indication that IT expenditures of all the banks under this study do not increase ROA, but rather decreases it significantly. This may be due to the fact that, investment in IT increases expense, as well as increasing assets and reduces operating profits, therefore reducing return on assets (ROA). The same can be said of the coefficient $\lambda_{1}$ as expansion in branches increases assets and due to competition in the industry, profits may be declining.

The estimated coefficient $\lambda_{6}$ is positive and statistically significant. Therefore, the effects of IT investments on increasing profitability (ROA) for high IT banks is significantly greater than that of low IT level banks. Therefore we fail to reject to the hypothesis that IT investments for high IT level banks has a positive impact on ROA.

\subsubsection{Returns on Equity (ROE)}

The interest margin (lmgn) is positive and statistically insignificant as expected since increases in margin tend to increase net profit and holding other things constant, ROE is expected to increase. As expected the coefficient of $\delta_{4}$ is negative as non-interest expenses tend to lower profits of banks and as such, lowers ROE all things being equal. Therefore it would be expected that for ROE to increase considerably, then $L N I E_{i t}$ must be kept in the barest minimum.

The estimated coefficient of $\delta_{5}$ is negative as has been the case with all the previous equations. This is an indication that IT expenditures of all the banks under study do not increase ROE, but rather decreases it significantly. However the estimated coefficient $\delta_{6}$ is positive, though not statistically significant. This therefore means that IT investments for high IT level banks has a positive impact on ROE than that of low IT level banks.

\section{Summary and Conclusions}

\subsection{Summary}

The objective of this study is to ascertain whether IT investments are positively related to financial performance of banks using an enhanced Balanced Scored Card (BSC) approach proposed by Kaplan and Norton (1992, 2001a, 2001b) and applied in the work of Davidson and Kim (2004). The proposed (i.e. modified for IT strategy) BSC framework attempts to track the key strategic role of IT suggested by previous studies and the links to performance measures.

This study covering 15 banks over a 10-year period (1998-2007) employed panel data regressions. The study finds that investments in IT tend to increase profitability (ROA \& ROE) for high IT level banks than for lower IT level banks. However the entire industry is not able to increase their profitability through the investments in IT. This may be due to the fact that generally the industry is becoming keenly competitive and returns are thus declining and without the investment in IT, banks would be worse off.

\subsection{Conclusions \& Managerial Implications}

The study shows that though High IT level banks have the tendencies to use IT investments to increase profitability 
in terms of ROA and ROE (financial perspective), the same can't be said of the entire industry. This is because of the negative results that the entire banks under this study exhibited in terms of the impact of IT investments on bank financial performance. This means that the strategic employment of IT would probably have the desired effect in the long-run than in the short-run as the study covered only 10 -years observation.

\section{References}

Bakos, J.Y. \& Kemerer, C.F. (1992). Recent Application of Economic Theory in Information Technology Research, Decision Support System Vol. 8: 365-386. doi:10.1016/0167-9236(92)90024-J, http://dx.doi.org/10.1016/0167-9236(92)90024-J

Bauer, H. H., Hammerschmidt, M. \& Falk, T. (2005). Measuring the quality of e-banking portals, International Journal of Bank Marketing, Vol. 23 No. 2. 153 - 175. doi:10.1108/02652320510584395, http://dx.doi.org/10.1108/02652320510584395

Bharadwaj, A S., Bharadwaj, S G., Konsynski, B.R. (1999). Information Technology Effects on Firm Performance as Measured by Tobin's q. Management Science, Vol. 45, No. 7. 1008-1024. doi:10.1287/mnsc.45.7.1008, http://dx.doi.org/10.1287/mnsc.45.7.1008

Bruque-Cámara, S., Vargas-Sánchez, A., \& Hernández-Ortiz, M.J. (2004). Organizational determinants of IT adoption in the pharmaceutical distribution sector, European Journal of Information Systems, v.13 (2). 133-146. doi:10.1057/palgrave.ejis.3000490, http://dx.doi.org/10.1057/palgrave.ejis.3000490

Brynfolfsson, E., \& Yang, S. (1996). Information Technology and Productivity. Advance in Computers, Academic Press, Volume 43, pages 179-214.

Brynjolfsson, E. (1993). The productivity paradox of Information Technology. Communications of the ACM, Vol. 36, No. 1 pp 67-77. doi:10.1145/163298.163309, http://dx.doi.org/10.1145/163298.163309

Brynjolfsson, E. \& Hitt, L. (1996). Paradox Lost? Firm Level evidence on the Returns to Information Systems Spending. Management Science, Vol. 42, pp. 541-558 doi:10.1287/mnsc.42.4.541, http://dx.doi.org/10.1287/mnsc.42.4.541

Brynjolfsson, E. and Hitt, L. (1998). Beyond the Productivity Paradox: Computers are the Catalyst for Bigger Changes, Communications of the ACM v.41 n.8, p.49-55. doi:10.1145/280324.280332, http://dx.doi.org/10.1145/280324.280332

Brynjolfsson, E. \& Hitt, L. (2001). Beyond computation: Information technology, organizational transformation and business performance. Unpublished, MIT, Cambridge, M.A

Brynjolfsson, E. \& Hitt, L. (1995). Information Technology as a Factor of Production: the Role of Differences among Firms, Economics of Innovation and New Technology, Vol. 3: 183-199. doi:10.1080/10438599500000002, http://dx.doi.org/10.1080/10438599500000002

Brynjolfsson, E., Hitt, L. \& Yang, S. (2000). Intangible assets: How the interaction of computers and organizational structure affects stock market valuations. MIT Working paper. (Online) Available: http://ecommere.mit.edu/erik/index.html

Brynjolfsson. E. \& Hitt, L. (1993). Is Information Systems Spending Productive? New Evidence and New Results. The Proceedings of the 14th International Conference on Information Systems, Orlando, FL.

Cash, J.I. Jr \& Konsynski B.R. (1985). Is redraws competitive boundaries. Harvard Business Review 63, 134-142

Checkly J. (1994). Electronic Banking and Security: Banking System Security. Brain Welch (ed), p. 47. UK: Basil Blackwell.

Coombs, R., Saviotti, P. \&Walsh, V. (1987). Economics and Technological Change. Macmillan: London.

Crowston, K. \& Tracy, M. E. (1986). Assessing the Impact Technology on Enterprise Level Performance. MIT Centre for Information Systems Research Working Paper, No. 143.

Dannenberg and Kellner, (1998). The bank of tomorrow with today's technology. (Online) available: http://www.emeraldinsight.com/10.1108/02652329810206743.

Dos Santos, B. L., Peffers K. G. \& Mauer, D. C.(1993). The Impact of Information Technology Investment Announcements on the Market Value of the Firm. Information Systems Research, 4(1): 1-23. doi:10.1287/isre.4.1.1, http://dx.doi.org/10.1287/isre.4.1.1

Economist. (1990). Working Harder, Doing Less, p. 17.

Gounaris, S., Dimitriadis, S. \& Stathakopoulos, V. (2005). Antecedents of perceived quality in the context of internet retail stores. Journal of Marketing Management, Vol. 21, Nos7-8, pp. 669 - 700. doi:10.1362/026725705774538390, http://dx.doi.org/10.1362/026725705774538390 
Hitt, L. \& Brynjolfsson, E. (1994). The three Faces of IT Value: Theory and Evidence, Proceedings of the $15^{\text {th }}$ International Conference on Information Systems Vancouver, B.C (December), pp.263-277.

Hitt, L. \& Brynjolfsson, E. (1995). Productivity without profit? Three measures of IT. Value. Sloan School of management, Working paper

Hitt, L. \& Brynjolfsson, E. (1996). Productivity, business profitability, and consumer surplus: three different measures of information technology value. MIS Quarterly. 20(2) 121-142. doi:10.2307/249475, http://dx.doi.org/10.2307/249475

Ige, O. (1995). Information Technology in a De-regulated Telecommunications Environment. Keynote address, INFOTECH 95, First International Conference on Information Technology Management, Lagos, November16-17.

Kaplan, R. S. \& Norton, D. P. (1992). The balanced scorecard - Measures that drive performance. Harvard Business Review. 71-79. PMid:10119714, http://dx.doi.org/10119714

Kaplan, R. S. \& Norton, D. P. (2001a). Transforming the Balanced Scorecard from Performance Measurement to Strategic Management. Part 1. Accounting Horizons. Vol 15 (1). pp. 87-104. doi:10.2308/acch.2001.15.1.87, http://dx.doi.org/10.2308/acch.2001.15.1.87

Kaplan, R. S. \&Norton, D. P. (2001b). Transforming the Balanced Scorecard from Performance Measurement to Strategic Management. Part II. Accounting Horizons. Vol 15 (2). 147-160. doi:10.2308/acch.2001.15.2.147, http://dx.doi.org/10.2308/acch.2001.15.2.147

Kaufman, F. (1966). Data Systems That Cross Company Boundaries. Harvard Business Review, Vol. 44 (No. 1) $141-5$

Kelley, S. (1989). Efficiency in service delivery: technologies or humanistic approaches? Journal for Services Marketing, Vol. 3 No. 3, 3-12. doi:10.1108/EUM0000000002492, http://dx.doi.org/10.1108/EUM0000000002492

Kemerer, C.F. \& Sosa, G. L. (1991). Systems Development Risks in Strategic Information Systems. Information and Software Technology, Vol. 33(3): 212-223, (April). doi:10.1016/0950-5849(91)90136-Y, http://dx.doi.org/10.1016/0950-5849(91)90136-Y

Kim, C \& Davidson, L. (2004). The Effects of I.T Expenditures on Banks Business Performance: Using the Balanced Score Card Approach. Managerial Finance, Volume 30. pages 28-45. doi:10.1108/03074350410769100, http://dx.doi.org/10.1108/03074350410769100

Langdon and Langdon. (2006). Managing Digital Firms. MIS Review

Lee G \& Lin H. (2005). Customer Perceptions of E-service Quality in Online Shopping. International Journal of Retail \& Distribution Management, Volume 33, No. 2, pages 3-12 doi:10.1108/09590550510581485, http://dx.doi.org/10.1108/09590550510581485

Levitt, T. (1992). The Globalisation of Markets, in: Transnational Management: Text, Cases and Readings in Cross-Border Management. Richard D. Irwin.

Lichtenberg, Frank R. (1995). The Output Contributions of Computer Equipment and Personal: A Firm-Level Analysis. Economics of Innovation and New Technology, Vol. 3: 201-217. doi:10.1080/10438599500000003, http://dx.doi.org/10.1080/10438599500000003

Lim, J. H., Richardson, V.J., \& Roberts, T.L. (2004). Information Technology Investment and Firm Performance: A Meta-Analysis. HICSS, vol. 8, pp.80221a, Proceedings of the 37th Annual Hawaii International Conference on System Sciences (HICSS'04) - Track 8.

Magnet, M. (1994). The Dream and the Nightmare: The Sixties' Legacy to the Underclass. HarperCollins Publishers, ISBN, 0688135129, 9780688135126.

Mandel, J. (1994). Analysis of two-way layouts. illustrated in CRC Press. ISBN, $0412986116,9780412986116$.

McFarlan, F.W. (1984). Information technology changes the way you compete. Harvard Business Review, 61(3), 98-103.

McLean, E.R. \& Soden, J.V. (1977). Strategic Planning for MIS. John Wiley and Sons.

O'Leary, T.J. Williams, B.K., and O'Leary, L. (1989). McGraw Hill Microcomputing. Annual Edition McGraw-Hill. Parsons, G. L. (1983). Information technology: A new competitive weapon. Sloan Management Rev. 25(1) 3 - 13.

Porter, M. E. \& Miller, V. E. (1985). How Information Gives You Competitive Advantage. Harvard Business Review, (63). 149-160.

Porter, M., (2001). Strategy and the Internet. Harvard Business Review, Vol.79 (3), $63-78$.

Quinn, J.B. \& Baily. M. N. (1994). Information technology: increasing productivity in services. Academy of Management Executive 8(3) 28 - 51. 
Rai, A., Patnayakuni, R., \& Patnayakuni, N. (1997). Technology Investment and Business Performance. Communications of the ACM, (40). 89-97. doi:10.1145/256175.256191, http://dx.doi.org/10.1145/256175.256191

Schneider, K. (1987). Services Hurt by Technology: Productivity is Declining. The New York Times, June 29: D1, D6.

Snow, C. P. (1966). Government Science and Public Policy. Science, Vol. 151: 650-653. doi:10.1126/science.151.3711.650 PMid:17813788, http://dx.doi.org/10.1126/science.151.3711.650.

Solow, R. M (1987). We'd Better Watch Out. New York Times Book Review, July 12.

Strassman, P. (1997). The Squandered Computer: evaluating the business alignment of information technology. The information Economics Press.

Strassmann, P. A. (1990). The Business Value of Computers: An Executive's Guide. New Canaan, CT, Information Economics Press.

Willcocks,L. \& Lester, S.(1999). Beyond the IT productivity paradox. illustrated, Wiley. Original from the University of Michigan (Nov 3, 2007) ISBN 0471986925, 9780471986928

Zachary, G. P. (1991). Computer Data Overload Limits Productivity Gains. Wall Street Journal. 81.

Table 1. Descriptive Statistics of variables \& One-Sample Statistics

\begin{tabular}{|c|c|c|c|c|c|c|c|c|}
\hline \multirow{2}{*}{} & \multicolumn{4}{|c|}{ Descriptive } & \multicolumn{3}{c|}{ One-Sample Test (Test Value = 0) } \\
\cline { 2 - 10 } & \multicolumn{3}{|c|}{ Df $\mathbf{1 5 0}$} & \multicolumn{3}{c|}{ 95\% Confidence Interval of the Difference } \\
\hline Variables & Mean & Std. Deviation & Min & Max & T & Sig. (2-tailed) & Lower & Upper \\
\hline LOPREX & 5.963 & 2.271 & 0.000 & 7.999 & 32.156 & .000 & 5.597 & 6.3299 \\
\hline MSD & 6.205 & 6.708 & 0.000 & 23.499 & 11.330 & .000 & 5.123 & 7.287 \\
\hline MSL & 6.179 & 7.007 & 0.000 & 34.169 & 10.800 & .000 & 5.048 & 7.309 \\
\hline LOPR & 5.581 & 2.486 & 0.000 & 8.153 & 27.493 & .000 & 5.179 & 5.982 \\
\hline ROE & 2.579 & 2.891 & -151.800 & 117.000 & 10.923 & .000 & 21.121 & 30.450 \\
\hline ROA & 2.817 & 4.201 & -34.200 & 10.120 & 8.211 & .000 & 2.138 & 3.494 \\
\hline LBPR & 1.233 & 0.619 & 0.000 & 5.084 & 24.395 & .000 & 1.133 & 1.333 \\
\hline LITEXP & 4.889 & 1.911 & 0.000 & 6.988 & 31.341 & .000 & 4.581 & 5.197 \\
\hline LITNDX & 2.004 & 2.854 & 0.000 & 6.988 & 8.598 & .000 & 1.543 & 2.464 \\
\hline LMGN & 5.978 & 2.361 & 0.000 & 7.953 & 31.008 & .000 & 5.597 & 6.359 \\
\hline EQTR & 42.367 & 90.343 & -45.246 & 997.295 & 5.743 & .000 & 27.791 & 56.942 \\
\hline BRAN & 20.52 & 33.174 & 0 & 136 & 7.591 & .000 & 15.170 & 25.870 \\
\hline GROWTH & 33.996 & 46.051 & -173.462 & 195.628 & 9.041 & .000 & 26.566 & 41.426 \\
\hline LNIR & 5.846 & 2.241 & 0.000 & 7.762 & 31.942 & .000 & 5.484 & 6.207 \\
\hline LNIE & 5.303 & 2.171 & 0.000 & 7.301 & 29.919 & .000 & 4.952 & 5.653 \\
\hline
\end{tabular}

Source: Author's computation

1. Variable names are in the body of the study

2. $S t d$ Dev $=$ Standard Deviation $N=$ The number of sample observations $d f=$ degree of freedom

3. ROA, ROE, EQTR, Growth, MSD, MSL and LBPR = percent and ratios per bank

4. The monetary unit for LOPREX, LOPR, ITEXP, ITNDX, ITDPX, LMGN, LNIR, LNIE variables is Ghanaian cedis which are logged because of the large figures

Table 1 shows the descriptive statistics of variables and one-sample statistics used in assessing the effects of I.T investments on banks' business performance. 
Table 2. Summary of Independent-Samples Test on IT Level (1998-2007 Pooled Data)

\begin{tabular}{|c|c|c|c|c|c|c|c|c|}
\hline \multirow[b]{2}{*}{ Variables } & \multicolumn{2}{|c|}{ Levene's Test for Equality of Variances } & \multirow[t]{2}{*}{ t-value } & \multirow[t]{2}{*}{$\begin{array}{c}\text { Sig. } \\
\text { (2-tailed) }\end{array}$} & \multicolumn{2}{|c|}{$\begin{array}{c}\text { High IT-Level Banks } \\
(\mathrm{N}: 50)\end{array}$} & \multicolumn{2}{|c|}{$\begin{array}{c}\text { Low IT-Level Banks } \\
(\mathrm{N}: 100)\end{array}$} \\
\hline & $\mathbf{F}$ & Sig. & & & Mean & Std. Dev & Mean & Std. Dev \\
\hline LOPREX & 43.241 & .000 & 6.684 & 0.000 & 7.142 & 0.433 & 5.374 & 2.573 \\
\hline MSD & 9.931 & .002 & 7.884 & 0.000 & 11.486 & 6.010 & 3.565 & 5.359 \\
\hline MSL & 3.708 & .056 & 8.567 & 0.000 & 11.865 & 5.991 & 3.335 & 5.624 \\
\hline LOPR & 71.854 & .000 & 7.867 & 0.000 & 7.058 & 0.437 & 4.842 & 2.748 \\
\hline ROE & 4.632 & .033 & $3.129 * *$ & 0.002 & 34.334 & 17.788 & 21.512 & 32.344 \\
\hline ROA & 2.477 & .118 & 3.812 & 0.000 & 4.587 & 2.019 & 1.931 & 4.709 \\
\hline LBPR & 6.266 & .013 & 4.994 & 0.000 & 1.561 & 0.560 & 1.069 & 0.583 \\
\hline LITEXP & 40.028 & .000 & 7.653 & 0.000 & 6.011 & 0.440 & 4.328 & 2.108 \\
\hline LITNDX & 131.154 & .000 & 96.628 & 0.000 & 6.011 & 0.440 & 0.000 & 0.000 \\
\hline LMGN & 49.762 & .000 & 7.160 & 0.000 & 7.274 & 0.413 & 5.330 & 2.652 \\
\hline EQTR & 2.337 & .128 & $-0.145 * *$ & 0.885 & 40.846 & 39.907 & 43.127 & 107.210 \\
\hline BRAN & 106.675 & .000 & 7.171 & 0.000 & 50.280 & 43.820 & 5.640 & 5.913 \\
\hline GROWTH & 0.161 & .689 & $0.138 * *$ & 0.891 & 34.730 & 43.353 & 33.629 & 47.551 \\
\hline LNIR & 45.621 & .000 & 7.019 & 0.000 & 7.055 & 0.385 & 5.241 & 2.526 \\
\hline LNIE & 48.596 & .000 & 7.639 & 0.000 & 6.569 & 0.451 & 4.669 & 2.403 \\
\hline
\end{tabular}

** mean significant at the $1 \%, 5 \%$ and $10 \%$ level (two-tail test) respectively. $N$ represents number of observations

Table 2summarises the outcome of the Levene's test for equality of variance and the summary of independent-samples Test on IT level of banks. This finds whether there is any significant difference on the effect of IT investments among two groups of banks- the high IT-Level investing banks and Low-IT level investing banks.

Table 3. Group unit root test: Summary Sample: 1150

\begin{tabular}{|l|l|l|l|l|}
\hline \multirow{2}{*}{ Method } & & & \multirow{2}{*}{ Cross-Sections } & \multirow{2}{*}{ Obs } \\
\cline { 2 - 5 } & Statistic & \multirow{2}{*}{ Prob.** } & & \\
\hline Null: Unit root (assumes common unit root process) & -11.592 & 0.000 & 15 & 2383 \\
\hline Levin, Lin \& Chu t* & -11.925 & 0.000 & 15 & 2367 \\
\hline Breitung t-stat & & & & \\
\hline \multicolumn{2}{|l|}{} & & \\
\hline Null: Unit root (assumes individual unit root process) & -15.054 & 0.000 & 15 & 2383 \\
\hline Im, Pesaran and Shin W-stat & 308.549 & 0.000 & 15 & 2383 \\
\hline ADF - Fisher Chi-square & 357.530 & 0.000 & 15 & 2384 \\
\hline PP - Fisher Chi-square & & & \\
\hline
\end{tabular}

Automatic selection of lags based on SIC: 0 to $1 .{ }^{* *}$ Probabilities for Fisher tests are computed using an asymptotic Chi-square distribution. All other tests assume asymptotic normality.

The summary test was used in order to ascertain the stationarity by both the common root and individual root methods. The results for the panel unit root test for all variables indicates the absence of a unit root as the LLC, Breitung, IPS, and both Fisher tests fail to accept the null of a unit root with statistics of $-11.592,-11.925,-15.054,308.549$ and 357.530 respectively.

Table 4. GLS Panel Regression results for Returns on Assets (ROA) and Return on Equity (ROE)

\begin{tabular}{|c|c|c|c|c|c|c|c|}
\hline \multicolumn{8}{|c|}{ 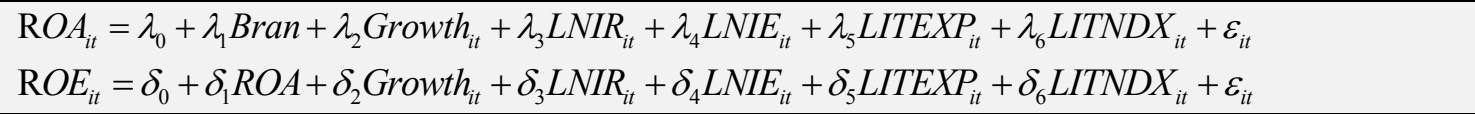 } \\
\hline \multicolumn{4}{|c|}{ Return on Asset (ROA) } & \multicolumn{4}{|c|}{ Return on Equity (ROE) } \\
\hline ROA & Coef. & Z-values & $\mathbf{P}>|\mathbf{z}|$ & ROE & Coef. & Z-values & $\mathbf{P}>|\mathbf{z}|$ \\
\hline Const & -0.7067 & -0.83 & 0.405 & Const & -2.0247 & -0.41 & 0.679 \\
\hline Bran & -0.0051 & -0.43 & 0.670 & Roa & 3.4304 & 7.31 & 0.000 \\
\hline Growth & 0.0183 & 2.69 & 0.007 & Lmgn & 5.9302 & 1.49 & 0.138 \\
\hline Lnir & 2.3954 & 3.53 & 0.000 & Lnir & 6.4615 & 1.26 & 0.207 \\
\hline Lnie & -0.8734 & -2.29 & 0.022 & Lnie & -3.3591 & -1.31 & 0.190 \\
\hline Litexp & -1.4839 & -2.19 & 0.029 & Litexp & -7.6357 & -1.93 & 0.054 \\
\hline Litndx & 0.4449 & 3.00 & 0.003 & Litndx & 0.0339 & 0.05 & 0.962 \\
\hline \multicolumn{3}{|c|}{ Wald $\mathrm{Chi}^{2}(6)$} & 45.98 & \multicolumn{3}{|c|}{ Wald $\mathrm{Chi}^{2}$ (6) } & 129.28 \\
\hline \multicolumn{3}{|c|}{ Prob $>\mathrm{Chi}^{2}$} & 0.000 & \multicolumn{3}{|c|}{ Prob $>\mathrm{Chi}^{2}$} & 0.000 \\
\hline
\end{tabular}

Note: P-values are under the column titled " $\mathrm{P}>|\mathrm{z}|$ " for the GLS model.

Table 4 shows the GLS regression results for IT investments on banks' financial performance (ROA \& ROE) with other control variables. 